\title{
The risk factors and prevention of cardiovascular disease: the importance of electrocardiogram in the diagnosis and treatment of acute coronary syndrome
}

\author{
This article was published in the following Dove Press journal: \\ Therapeutics and Clinical Risk Management \\ 8 August 2016 \\ Number of times this article has been viewed
}

\author{
Anna Rosiek' \\ Krzysztof Leksowski ${ }^{1,2}$ \\ 'Department of Public Health, \\ Faculty of Health Sciences, \\ Nicolas Copernicus University \\ in Toruń, ${ }^{2}$ Department of General \\ Surgery, I0th Military Hospital, \\ Bydgoszcz, Poland
}

Correspondence: Anna Rosiek Department of Public Health, Faculty of Health Sciences, Nicolas Copernicus University in Toruń, Przodowników Pracy 8/7, 85-843 Bydgoszcz, Poland Tel/fax +4852 38I 4772

Email ania.rosiek@wp.pl

\begin{abstract}
Acute coronary syndrome is a leading cause of emergency medical treatment and hospitalization in Poland. High-speed electrocardiogram (ECG) has shown good accuracy of the initial diagnosis and of the final diagnosis in treated cardiac patients. Initial diagnosis and definitive diagnosis were analyzed statistically $(P<0.0001)$. Although much is said about the prevention of sudden death in heart failure, the elimination of risk factors health care in Poland does not pay due attention to the need for early diagnosis and ECG analysis (at the stage of prevention). This article presents the inclusion of ECG in the prevention process and shows that it allows for early detection of cardiovascular diseases. In Poland, ST-segment elevation myocardial infarction patients are identified in the ambulance that reduces time to door-to-balloon.
\end{abstract}

Keywords: electrical intervention, chest pain, health care delivery, diagnostics, signal transmission, death prevention

\section{Introduction}

Cardiovascular diseases are the main cause of premature deaths and disabilities, a source of rising health care costs, mainly in developed countries and increasingly common problem in developing countries. The deaths caused by cardiovascular diseases in Europe make up $48 \%$ of all deaths (males $38 \%$ and females $54 \%$ ). ${ }^{1}$ In Poland, deaths caused by complications of cardiovascular diseases are similar to the levels in Europe: $41 \%$ in males and $52 \%$ in females.

According to "Policy paper for health care 2014-2020"2 comparing the volume of deaths caused by leading most important causes of death in Poland and the European Union, we can see that in terms of life-threatening cardiovascular diseases caused by Polish society are in a worse situation than societies in other European Union countries.

However, it should be noted that since 1991, in Poland, we can observe a decrease in mortality rate caused by complications of cardiovascular diseases, including reduction of mortality rate caused by coronary heart disease. In 2014 , the decrease was $42 \%$. These advantageous changes are related in $54 \%$ to a decrease of risk factors and in $37 \%$ to better medical treatment. The remaining $9 \%$ of decrease in mortality could not be explained.

The decrease in cholesterol was related to $39 \%$ lowering of mortality and the decrease in smoking and improvement of physical activity, respectively, to $11 \%$ and $10 \%$ decrease in mortality. However, in this period, obesity and diabetes increased, 
Table I The division of risk factors according to the European Guidelines on cardiovascular disease prevention in clinical practice

\begin{tabular}{lll}
\hline Individual factors & Biochemical and physiological factors & Lifestyle \\
\hline - Age & - Hypertension & - Smoking \\
- Sex & - Increased levels of total cholesterol fraction - LDL & - Unhealthy diet \\
- Family history of cardiovascular diseases & - Low levels of cholesterol fraction - HDL & - Low physical activity \\
- Genetic markers & - Increasing the concentration triglycerides & \\
& - Diabetes & - Obesity \\
& - Procoagulant factors & \\
& - Markers of chronic inflammation & - ECG monitoring of heart
\end{tabular}

Note: Data from a previous study. ${ }^{4}$

Abbreviations: ECG, electrocardiogram; HDL, high-density lipoprotein; LDL, low-density lipoprotein.

which in turn was associated with mortality increases by $2 \%$ and 3\%, respectively. ${ }^{1,2}$ According to data from the Central Statistical Office, cardiovascular diseases were major cause of all deaths in Poland in 2014. ${ }^{3}$

According to the European Guidelines on cardiovascular disease prevention in clinical practice, risk factors are divided into individual factors, physiological and biochemical factors, and lifestyle (Table 1). ${ }^{4}$

Monitoring of certain factors, biochemical and physiological ones, is important in the prevention of diseases of the cardiovascular system. However, the list of biochemical and physiological factors (besides markers of chronic inflammation and level of triglycerides) should, in the author's opinion, include monitoring of heart beat electrical signal (electrocardiogram [ECG]), which should be carried out not only in case of danger to life but also in the case of the wider system of prevention of cardiovascular diseases or heart diseases.

\section{Biochemical and physiological risk factors Hypertension}

Hypertension (abnormally high blood pressure) is a risk factor when it comes to cardiovascular disorder both for hemodynamic reasons (hemorrhagic stroke and aortic dissection) and because of the acceleration of atherosclerosis. ${ }^{5}$ In 2000, 972 million adults worldwide suffered from hypertension, including 639 million in the industrialized countries. ${ }^{6}$ In 2005, hypertension was diagnosed in 1.5 billion people. ${ }^{7}$ The presence of hypertension in Polish society is high. The comparative study of the prevalence of blood pressure and awareness of respondents about the disease, control, and treatment of hypertension conducted by Rywik et al, ${ }^{8}$ showed that the average blood pressure values were $15 \%$ higher in the Polish population than in the US population, while optimal blood pressure was found in $\sim 2 \%$ of respondents in Poland and $55 \%$ of those in the US.

\section{Overweight body mass and obesity}

In the National Health and Nutrition Examination Survey III study conducted in the US, it was demonstrated that $68 \%$ of the population has an abnormal body mass: $34.2 \%$ of overweight people and $33.8 \%$ of obese people. ${ }^{9}$ The incidence of obesity in Europe was rated at $25 \%$ for males and $30 \%$ for females. ${ }^{10}$ In the study representative for the Polish population (WOBASZ), the prevalence of excess weight was observed in $61.6 \%$ of males and $50.3 \%$ of females. ${ }^{11}$ Worrying contributes to the increasing percentage of people with abnormal body weight. In the last 17 years, average body mass increased by $3.3 \mathrm{~kg}$ in males and by $5 \mathrm{~kg}$ in females. ${ }^{11}$ The Polish arm of the WHO MONICA Project also observed a progressive, year-after-year, increase in body weight in Polish society, which ranges from 0.3 to $0.7 \mathrm{~kg} /$ year. ${ }^{12}$

\section{Dyslipidemia}

Lipid disorders are modifiable risk factors of cardiovascular diseases. According to the current guidelines, the level of cholesterol for general population is $<190 \mathrm{mg} / \mathrm{dL}$ $(5 \mathrm{mmol} / \mathrm{L})$, the level of low-density lipoprotein cholesterol fraction is $<115 \mathrm{mg} / \mathrm{dL}$ ( $3 \mathrm{mmol} / \mathrm{L}$ ), the level of high-density lipoprotein cholesterol fraction is $>40 \mathrm{mg} / \mathrm{dL}(1.0 \mathrm{mmol} / \mathrm{L})$ in males and $45 \mathrm{mg} / \mathrm{dL}(1.2 \mathrm{mmol} / \mathrm{L})$ in females, and the level of triglyceride is $<150 \mathrm{mg} / \mathrm{dL}(1.7 \mathrm{mmol} / \mathrm{L})$.

The incidence of elevated level of cholesterol in both males and females in NATPOL PLUS amounted to 59.5\% and $62 \%$, respectively. ${ }^{13}$ WOBASZ study also confirmed the presence of higher concentrations of cholesterol in males (67\%) and females (64\%). Similarly, increased value was found in WOBASZ Senior study $-43 \%$ in males and $62 \%$ in females.

\section{Diabetes}

Diabetes is a group of metabolic diseases characterized by elevated levels of glucose in the blood resulting from a defect in insulin secretion or action. ${ }^{14}$ In the European population, taking into account the age and unknown diabetes, 
the incidence of diabetes is $\sim 30 \%-40 \%{ }^{15}$ In WOBASZ study, diabetes or glycation $(126 \mathrm{mg} / \mathrm{dL})$ was observed in $\sim 7 \%$ of males and $6 \%$ of females aged between 20 and 74 years and in $16 \%$ of males and $20 \%$ of females aged between 65 and 74 years. ${ }^{11}$ Diabetes is usually associated with atherogenic dyslipidemia. Elevated concentration of glucose in blood enhances glycation mainly of low-density lipoprotein cholesterol, particle which becomes more susceptible to oxidation, is cytotoxic to the endothelium, and promotes the adhesion of blood platelets, ${ }^{16}$ which in turn promotes the development of cardiovascular diseases.

\section{Procoagulant factors}

Fibrinogen is an acute phase protein and is one of the main elements of coagulation. Its increased concentration is related to a significantly higher severity of atherosclerosis and a higher risk of heart diseases. An increase of $1 \mathrm{~g} / \mathrm{L}$ concentration of fibrinogen increases the risk of cardiovascular events twice. The factors of coagulation and fibrinolysis are as follows: clotting factors VII, von Willebranda factors, plasminogen activator inhibitor type 1 , and also tissue-type plasminogen activator. ${ }^{17}$

\section{Markers of inflammation}

The parameters evaluating the intensity of the inflammatory process are increased leukocyte concentration in serum C-reactive protein (CRP), fibrinogen, and interleukin-1, -6, and $-8 .{ }^{18}$ To study the intensity of the inflammatory process, we most commonly evaluate the CRP, as its presence can be marked in the blood of a person who had already eaten during a day. In addition, CRP is characterized by a relatively constant concentration throughout the day and not inactivated at low temperatures. ${ }^{19}$ A meta-analysis of long-lasting observation of patients with acute coronary syndrome (ACS) showed that the concentration of CRP has a significant impact on the further course of coronary heart disease. ${ }^{20}$

\section{Prevention of sudden death: European and Polish trends}

According to the authors, in addition to the factors described earlier, an essential element in the prevention of heart disease in Polish society and European population is the organization of medical care. Regular ECG, dedicated to all employees as part of periodic tests, can effectively prevent sudden death due to untreated and never-before detected cardiovascular disease. Our previous study has shown that cardiac patients without prior diagnosis of diseases of the cardiovascular system hesitate to call medical help even if they experience symptoms. ${ }^{21}$
Factors, such as female sex, low education level, socioeconomic status, age, and place of living, are associated with delays in seeking medical treatment. ${ }^{21-24}$ In addition, our previous study showed that ECG signal was performed but not transmitted to the reference center and transport took place in two stages. Intervals for the analyzed group of patients were statistically significant $(P<0.0001) .{ }^{21}$

In $53 \%$ of the analyzed group of patients, it was found that the time that elapsed from admission to the start of coronary angioplasty in referral center was $>90$ minutes. In addition, it should be noted that the weak point in the process of treating a patient with ACS proved to be patients who decided to call an ambulance 140 minutes (average time) after the onset of pain. Public education by mass media could increase public awareness of ACS and could reduce delay in presenting the ECG data to the reference center. ${ }^{21}$ Thorough education of emergency staff on how important an ECG signal transmission is to the reference center in cases of heart failure may successfully prevent a sudden death.

Early ECG recordings in ACS are a key step to ensure a timely triage of patients who are candidates for an early invasive treatment. The trained paramedics can diagnose ST-segment elevation myocardial infarction (STEMI) correctly in patients without ECG confounding factors, while the presence of ECG confounding factors decreased their ability substantially. Consequently, since many patients were present with ECG confounding factors, transmission to an on-call cardiologist for an early correct diagnosis is needed. It decreases time necessary to start hospitalization and saves the patient's life. Prehospital ECGs can help to identify ST-segment elevation earlier and detect important transient abnormalities, information not otherwise available from the first emergency department ECG. ${ }^{25,26}$ These data can expedite diagnosis and clinical management decisions concerning patients suspected of having an acute cardiac event. We must also remember that in case of STEMI, patients transported even on short distances are in danger of developing arrhythmic complications. Early ECG recordings in ACS not only influence the time of transport to nearest hospital with the catheterization laboratory but also increase the effectiveness of treatment and improve patients' survival ratio. The prehospital ECG should be fully integrated into emergency practices. ${ }^{25}$ Investigated whether ST-segment elevation on the initial ECG could provide prognostic information and thereby decision support for appropriate triage. Once the triage decision is settled, patients with STEMI must undergo ECG monitoring and receive antithrombotic therapy for optimal prehospital care. ${ }^{26}$ Prehospital antithrombotic therapy must be effective in preparing the patient for 
percutaneous coronary intervention (PCI) without causing bleeding or less bleeding events. ${ }^{26}$ It decreases potential complications for patients treated invasively. The benefits of transmitting prehospital ECG to a cardiologist's hand-held device are visible both for patients and health care. Triage and activation of the catheterization laboratory are done when needed. It decreases the costs of treatment, improves accessibility to the laboratory, and gives better results of treating patients with cardiac events. The optimal treatment strategy is dependent on the duration of ischemia. ${ }^{25,26}$ However, patients' information is often inaccurate..$^{25,26}$ Accordingly, it would be advantageous if the first available ECG recording done by paramedics could help identify patients who would benefit in greater degree from acute reperfusion therapy versus patients with modest effects. ${ }^{26}$ An interactive module used by paramedics (ECG recorder) for treating cardiology patients improved the ability of paramedics and emergency medical staff to correctly recognize the ECG and interpret the ECG's ST-segment elevation. The use of technology and ECG recordable device is necessary to help identify patients who immediately require lifesaving procedures. To conclude, general benefits of an early invasive strategy in patients with heart failure is lifesaving in life-threatening situations, which may successfully prevent sudden death. Successful management of ST-segment elevation ACS by early invasive therapy improves long-term survival and reduces late myocardial infarction (MI) and rehospitalization for unstable angina (UA). Stents enhance the safety of PCI by decreasing major adverse cardiac events, including MI and death. ${ }^{27,28}$ Also early invasive therapy decreases nonfatal MI by $17 \%$ and recurrent UA requiring rehospitalization by $31 \% .^{28}$

The American Heart Association Guidelines for Cardiopulmonary Resuscitation and Emergency Cardiovascular Care of 2010 suggest that postcardiac arrest hospital treatment has potential to reduce mortality caused by hemodynamic body instability. ${ }^{21,29-31}$ Hemodynamic optimization and multidisciplinary early goal-directed therapy have been introduced as part of a bundle of care to improve patient outcome and to ensure better organ perfusion and oxygenation of organs and give the positive results of treatment in case of cardiology patients. ${ }^{21,30,32}$

Primary prevention of coronary heart disease causes a much greater reduction in mortality in the general population than secondary prevention. Comparative studies of people with coronary heart disease and healthy individuals have shown that lowered systolic blood pressure, reduced blood cholesterol, and reduced incidence of smoking resulted in
$79 \%$ reduction of mortality caused by ischemic heart disease in primary prevention and $21 \%$ reduction of mortality in secondary prevention. This is confirmed by a study conducted in the US between 1980 and 2012. ${ }^{33}$ The importance of primary prevention has also been demonstrated in clinicalcontrol INTERHEART study ${ }^{34}$ conducted in 52 countries. The risk of a first heart attack is $90.4 \%$ and was associated with the following risk factors: smoking, diabetes, hypertension, psychosocial factors, obesity, a higher ratio ApoB/ ApoA1, low intake of fruits and vegetables, lack of physical exercise, and excessive alcohol consumption. This relationship was observed regardless of sex, ethnological origin, or geographical region. ${ }^{35}$ Primary prevention, because of its importance in society, was further examined and discussed in the literature. This fact is also confirmed by the number of studies conducted in different countries (WOBASZ and INTERHEART). However, by including primary prevention in the early and regularly exercised ECG (which has so far been overlooked), we can effectively reduce population mortality from diseases of the cardiovascular system. That is why it is worth paying attention to this element when considering the prevention of sudden death in heart failure.

Undoubtedly, prevention also consists of such therapeutic interventions and treatment of patients that reduce the incidence of complications (including death) and relapse, as well as inhibit the progression of pathological changes. Modification of risk factors is an essential strategy both in primary prevention and in secondary prevention. In secondary prevention of heart diseases, drug therapy plays an equally important role as the risk factor modification. ${ }^{36}$ However, the problem of modification of risk factors, especially those involving the health care organizations, has not been sufficiently discussed yet, and a list of biochemical and physiological factors has not been optimally configured. This topic is worth exploring in depth, because in 2011, there were 89,000 of people hospitalized because of heart attack in Poland and 16,000 Polish citizens died. With a relatively low hospital mortality, the rate of distance (before and after stay at the hospital) mortality becomes alarming. For this reason, it is important to early and rapidly diagnose the patients using ECG at both the prevention stage and early diagnosis stage, which is connected with the detection ability of cardiovascular diseases.

Monitoring of ECG is a widely used and inexpensive diagnostic method to investigate various cardiac abnormalities. It is a first-line investigation in MI. In ECG, ST-segment changes and $\mathrm{T}$-wave inversion criteria are mainly used for acute MI detection, but they have low sensitivity range from 
$10 \%$ to $50 \%$ as mentioned in different studies. ${ }^{37,38}$ Another drawback of this criterion is its transient nature, which means it is only present in ECG at the time of ischemic attack. ${ }^{37,38}$ Although prehospital diagnosis done by ECG transmitted to an expert for interpretation reduces the time till acute PCI in patients with STEMI. So finding the features that give information about MI or about risk of MI during emergency is quite useful for both patients and doctors. Reducing the time of reperfusion treatment for patients with STEMI can improve patient outcomes, ${ }^{38}$ and also every delay in PCI increases long-lasting mortality. ${ }^{39}$ The recording of prehospital 12-lead ECG in chest pain patients ensures reducing time to $\mathrm{PCI}^{40}$ and is an established tool to a correct and timely treatment for patients in health care unit. ${ }^{41}$ In order not to miss any STEMI cases, it is recommended that all ambulances transport patients with symptoms suggesting ACS to physician on call and coronary care unit. ${ }^{38-41}$

\section{Electrocardiograms}

An ECG is a noninvasive test that measures the electrical activity of the heart beat and also provides information about heart muscle damage, types and kinds of arrhythmias (abnormal heart rhythms), and signs of a heart attack and informs whether an internal cardioverter defibrillator or a pacemaker is working properly. ECGs and other vital sign monitoring are conducted continuously in critical care environments, such as the intensive care unit, coronary care unit and cardiac catheterization, and diagnostic stress testing labs. ECGs are also routinely performed in physician offices and other medical facilities. ${ }^{38,39}$

The ECG may show evidence of a heart attack, allowing doctors to prepare for immediate treatment of patient's arrival to hospital. A crucial step in effective STEMI treatment is swift transmission of an ECG image from emergency medical staff on site with a patient directly to the hospital to be viewed by a doctor. Traditionally ECG images are sent through specialized systems. Some hospitals use cell phones to take photos of ECGs, which require large files to maintain clarity and can be slow and unreliable, particularly images taken by emergency medical personnel in signal-limited environments. ${ }^{21,38,39,41}$ A final ECG interpretation and triage decision by a physician is therefore clearly needed to avoid unnecessary catheterization laboratory activation. Early interpretation could also help in increasing the number of prehospital ECGs on record and increase the number of patients with STEMI identified in the ambulance. These facts reducing time to door-to-balloon. ${ }^{42}$

Initial diagnosis using the ECG signal transmission (diagnosis based on first transmission of ECG signal) coincides with the final diagnosis (the final diagnosis confirmed by a specialist - a cardiologist) and needs a careful analysis of pain history and symptoms, suggesting that other causes of chest pain (such as aortic dissection), comorbidities, are usually important information for the final triage decision. Moreover, a high specificity in hospital triage decision is needed because coronary angiographies carry high risk of complications for patients. Apart from this, the results of our previous study indicate a very low number of ambulance personnel who transmit an ECG in analyzed group of 270 patients in KujavianPomeranian region in Poland. ${ }^{21}$ However, the presence of STEMI in our study was comparable with the estimated real prevalence in the prehospital setting. Our study and other researchers indicate that ambulance paramedics can interpret the ECG without fail, ${ }^{21,24}$ and transmits the ECG signals to a doctor, but this requires additional training for paramedics in ambulance ${ }^{21,24}$ and improving awareness about how the decision about sending the ECG signal or not influences the other steps of treatment and costs of patients' treatment.

According to the authors, the inclusion of an element such as ECG monitoring of biochemical and physiological factors is necessary, in order to effectively prevent premature death from heart disease. The necessity was confirmed by other reports, which show that there are $\sim 10$ million heart attacks worldwide per year ${ }^{43}$ in the US. It is also estimated that 500,000 STEMI events represent one-third of all heart attacks per year. ${ }^{44}$ Acute STEMI, UA, and non-ST-segment elevation MI (NSTEMI) are the three conditions classified as $\mathrm{ACS}{ }^{43,44} \mathrm{ACS}$ is a major cause of emergency medical treatment and hospitalization in the US and also in other countries in Europe. ${ }^{43,44}$

ECG findings related to UA include ST-segment depression, transient ST-segment elevation, T-wave inversion, and also some combination of these factors; depending on the severity of the clinical presentation, these findings are present in $30 \%-50 \%$ of patients. ${ }^{22,45}$ An ST-segment elevation of $\geq 0.1 \mathrm{mV}$, if present in at least two adjacent leads, indicates an acute $\mathrm{MI}$ in $90 \%$ of patients, as confirmed by serial measurements of cardiac biomarkers. ${ }^{46}$ It is important to compare current and former findings on ECG because studies suggest that patients without ECG changes are at a lower risk of complications than those with ECG changes. ${ }^{47}$ Because the process of myocardial ischemia is quite dynamic and a single 12-lead ECG provides only a snapshot view of this process, the American College of Cardiology and American Heart Association guidelines recommend that patients hospitalized for UA/NSTEMI undergo serial ECG tracings or continuous ST-segment monitoring. ${ }^{48}$ The physical examination may 
also carry trail that can help in determining the differential diagnosis. For example, unequal pulses or ripple of aortic regurgitation indicates possible aortic dissection, seeing that a pericardial friction rub suggests acute pericarditis. ${ }^{47,48}$ The relevance of the admission diagnoses and their compliance with the final diagnosis in patients with STEMI/UA or NSTEMI are really important for patients especially when diagnosis is done by emergency teams in ambulance and the ECG signal was transmitted to reference clinic. Early transmission of ECG signal can help to assess patient's condition and is one of the very good methods of prevention of sudden death in heart failure.

\section{Conclusion}

ECG transmission, along with subsequent cardiac consultation, credibly identifies patients with ACS, especially STEMI. Early transmission of ECG signal is a good method of prevention of sudden death in heart failure. Our previous study shows that scoring initial diagnosis using the ECG signal transmission coincides with the final diagnosis, which confirms the high efficiency of transmission of the ECG signal and reduces the time necessary intervention in STEMI and NSTEMI/UA. To provide a better prevention of sudden death in heart failure, the authors recommended additional training for all emergency staff and improving awareness about how and why the decision about sending (or not sending) the ECG signal to the reference center can help save life. Moreover, early detection of cardiovascular disease by ECG included as a compulsory study for primary prevention in the Polish population will effectively eliminate the premature mortality. Expansion of the list of biochemical and physiological factors to include an element of ECG monitoring will allow for an early detection of symptoms of the disease activity and will consequently help to protect the Polish population against sudden death from heart disease.

\section{Acknowledgment}

We would like to thank all contact persons.

\section{Disclosure}

The authors report no conflicts of interest in this work.

\section{References}

1. Cierniak-Piotrowska M, Marciniak G, Stańczak J [webpage on the Internet]. Zachorowalność i umieralność na choroby układu krążenia a sytuacja demograficzna Polski, Main Stsistical Office. 2015. Available from: http://bip.stat.gov.pl/organizacja-statystyki-publicznej/rzadowarada-ludnosciowa/publikacje-rzadowej-rady-ludnosciowej. Accessed June 29, 2016.
2. [webpage on the Internet]. Policy paper dla ochrony zdrowia na lata 2014-2020 Krajowe Strategiczne Ramy. Warsaw: 2014. Available from: http://www.zdrowie.gov.pl/aktualnosc-34-2133 Policy_paper_ dla_ochrony_zdrowia_na_lata_2014_2020_Krajowe_Strategiczne_ Ramy.html. Accessed June 29, 2016.

3. Central Statistical Office [homepage on the Internet]. Podstawowe dane z zakresu ochrony zdrowia w 2014 roku. Available from: http://www. stat.gov.pl. Accessed June 29, 2016.

4. De Backer G, Ambrosioni E, Borch-Jochnsen K, et al. European guidelines on cardiovascular disease prevention in clinical practice. Third Joint Task Force of European and Other Societies on Cardiovascular Disease Prevention in Clinical Practice. Euro Heart J. 2003;24(17):1601-1610.

5. Aboulhosn J, Child JS. Congenital heart disease for the adult cardiologist. Circulation. 2006;114:2412-2422.

6. Kearney PM, Whelton M, Reynolds K, Muntner P, Whelton PK, He J. Global burden of hypertension: analysis of worldwide data. Lancet. 2005;365(9455):217-223.

7. Chockalingam A. World hypertension day and global awareness. Can J Cardiol. 2008;24(6):441-444.

8. Rywik S, Wągrowska H, Szcześniewska D, et al. Worldwide isolated systolic hypertension prevalence evaluation study - polish part: polWISHE. Nadciśnienie Tętnicze. 2001;1:9-20.

9. Zhu S, Wang Z, Shen W, Heymsfield SB, Heshka S. Percentage body fat ranges associated with metabolic syndrome risk: results based on the third National Health and Nutrition Examination Survey (1988-1994). Am J Clin Nutr. 2003;78(2):228-235.

10. Nyholm M, Gullberg B, Merlo J, Lundqvist-Persson C, Råstam L, Lindblad $U$. The validity of obesity based on self-reported weight and height: implications for population studies. Obesity (Silver Spring). 2007;15(1):197-208.

11. Broda G, Rywik S. Wieloośrodkowe ogólnopolskie badanie stanu zdrowia ludności - projekt WOBASZ. Zdefiniowanie problemu oraz cele badania. Kardiol Pol. 2005;63(suppl. 4):1-4.

12. WHO MONICA Project. MONICA Manual, Part III: Population Survey, Section 1: Population Survey Data Component. Vol. 2012. Geneva: World Health Organization; 1997.

13. Zdrojewski T, Bandosz P, Szpakowski P, et al. Rozpowszechnienie głównych czynników ryzyka chorób układu sercowo-naczyniowego w Polsce. Wyniki badania NATPOL-PLUS. Kardiol Pol. 2004;61(suppl 4): $15-17$.

14. Dardano A, Penno G, Del Prato S, Miccoli R. Optimal therapy of type 2 diabetes: a controversial challenge. Aging (Albany NY). 2014;6(3): 187-206.

15. Peters AL. Patient and treatment perspectives: revisiting the link between type 2 diabetes, weight gain, and cardiovascular risk. Cleve Clin J Med. 2009; 76(suppl 5):S20-S27.

16. Orekhov AN, Bobryshev YV, Sobenin IA, Melnichenko AA, Chistiakov DA. Modified low density lipoprotein and lipoproteincontaining circulating immune complexes as diagnostic and prognostic biomarkers of atherosclerosis and type 1 diabetes macrovascular disease. Int J Mol Sci. 2014;15(7):12807-12841.

17. John C, Chapin JC, Hajjar KA. Fibrinolysis and the control of blood coagulation. Blood Rev. 2015;29(1):17-24.

18. Hung J, Knuiman MW, Divitini ML, Davis T, Beilby JP. Prevalence and risk factor correlates of elevated C-reactive protein in an adult Australian population. Am J Cardiol. 2008;101(2):193-198.

19. Ridker PM, Hennekens CH, Buring JE, Rifai N. C-reactive protein and other markers of inflammation in the prediction of cardiovascular disease in women. N Engl J Med. 2000;342(12):836-843.

20. Kones R. Rosuvastatin, inflammation, C-reactive protein, JUPITER, and primary prevention of cardiovascular disease - a perspective. Drug Des Devel Ther. 2010;4:383-413.

21. Rosiek A, Rosiek-Kryszewska A, Leksowski Ł, Leksowski K. A comparison of direct and two-stage transportation of patients to hospital in Poland. Int J Environ Res Public Health. 2015;12(5):4572-4586. 
22. Savonitto S, Ardissino D, Granger CB, et al. Prognostic value of the admission electrocardiogram in acute coronary syndromes. JAMA. 1999; 281(8):707-713

23. Zimmerman J, Fromm R, Meyer D, et al. Diagnostic marker cooperative study for the diagnosis of myocardial infarction. Circulation. 1999; 99(13):1671-1677.

24. Whitbread M, Leah V, Bell T, Coats TJ. Recognition of ST elevation by paramedics. Emerg Med J. 2002;19(1):66-67.

25. Boothroyd LJ, Segal E, Bogaty P, et al. Information on myocardial ischemia and arrhythmias added by prehospital electrocardiograms. Prehosp Emerg Care. 2013;17(2):187-192.

26. Ripa MS. The ECG as decision support in STEMI. Dan Med J. 2012; 59(3):B4413.

27. Zhu MM, Feit A, Chadow H, Alam M, Kwan T, Clark LT. Primary stent implantation compared with primary balloon angioplasty for acute myocardial infarction: a meta-analysis of randomized clinical trials. $\mathrm{Am}$ J Cardiol. 2001;88(3):297-301.

28. Bavry AA, Kumbhani DJ, Rassi AN, Bhatt DL, Askari AT. Benefit of early invasive therapy in acute coronary syndromes: a meta-analysis of contemporary randomized clinical trials. J Am Coll Cardiol. 2006; 48(7):1319-1325.

29. Neumar RW, Nolan JP, Adrie C, et al. Post-cardiac arrest syndrome: epidemiology, pathophysiology, treatment, and prognostication. A consensus statement from the International Liaison Committee on Resuscitation (American Heart Association, Australian and New Zealand Council on Resuscitation, European Resuscitation Council, Heart and Stroke Foundation of Canada, InterAmerican Heart Foundation, Resuscitation Council of Asia, and the Resuscitation Council of Southern Africa); the American Heart Association Emergency Cardiovascular Care Committee; the Council on Cardiovascular Surgery and Anesthesia; the Council on Cardiopulmonary, Perioperative, and Critical Care; the Council on Clinical Cardiology; and the Stroke Council. Circulation. 2008;118(23):2452-2483.

30. Peberdy MA, Callaway CW, Neumar RW, et al; American Heart Association. Part 9: post-cardiac arrest care: 2010 American Heart Association Guidelines for cardiopulmonary resuscitation and emergency cardiovascular care. Circulation. 2010;122(18 suppl 3): S768-S786.

31. Safar P. Resuscitation from clinical death: pathophysiologic limits and therapeutic potentials. Crit Care Med. 1988;16(10):923-941.

32. Kirves H, Skrifvars MB, Vähäkuopus M, Ekström K, Martikainen M, Castren M. Adherence to resuscitation guidelines during prehospital care of cardiac arrest patients. Eur J Emerg Med. 2007;14(2): 75-81.

33. Roger VL, Go AS, Lloyd-Jones DM, et al; American Heart Association Statistics Committee and Stroke Statistics Subcommittee. Heart disease and stroke statistics-2012 update: a report from the American Heart Association. Circulation. 2012;125(1):e2-e220.

34. Yusuf S, Hawken S, Ounpuu S, et al; INTERHEART Study Investigators. Effect of potentially modifiable risk factors associated with myocardial infarction in 52 countries (the INTERHEART study): case-control study. Lancet. 2004;364(9438):937-952.

35. Hudzik B, Szkodziński J. Profilaktyka wtórna choroby wieńcowej. Choroby serca i naczyń. 2008;5(4):186-189.

36. Herring N, Paterson DJ. ECG diagnosis of acute ischemia and infarction: past, present and future. QJM. 2006;99(4):219-230.
37. Ginn PH, Jamieson B, Mendoza MD. Clinical Inquiries. "How accurate is the use of ECGs in the diagnosis of myocardial infarct?" J Fam Pract. 2006;55(6):539-540.

38. De Luca G, Suryapranata H, Ottervanger JP, Antman EM. Time delay to treatment and mortality in primary angioplasty for acute myocardial infarction: every minute of delay counts. Circulation. 2004;109(10): $1223-1225$.

39. Terkelsen CJ, Sørensen JT, Maeng M, et al. System delay and mortality among patients with STEMI treated with primary percutaneous coronary intervention. JAMA. 2010;304(7):763-771.

40. Sejersten M, Sillesen M, Hansen PR, et al. Effect on treatment delay of prehospital teletransmission of 12-lead electrocardiogram to a cardiologist for immediate triage and direct referral of patients with ST-segment elevation acute myocardial infarction to primary percutaneous coronary intervention. Am J Cardiol. 2008;101(7):941-946.

41. Bradley EH, Nallamothu BK, Curtis JP, et al. Summary of evidence regarding hospital strategies to reduce door-to-balloon times for patients with ST-segment elevation myocardial infarction undergoing primary percutaneous coronary intervention. Crit Pathw Cardiol. 2007;6(3) 91-97.

42. Forberger JL, Khoshnood A, Green M. An artificial neural network to safely reduce the number of ambulance ECGs transmitted for physician assessment in a system with prehospital detection of ST elevation myocardial infraction. Scand J Trauma Resusc Emerg Med. 2012;20:8.

43. Lloyd-Jones D, Adams R, Carnethon M, et al; American Heart Association Statistics Committee and Stroke Statistics Subcommittee. American Heart Association Statistics Committee and Stroke Statistics Subcommittee Heart disease and stroke statistics-2009 update. A report from the American Heart Association Statistics Committee and Stroke Statistics Subcommittee [published correction appears in Circulation. 2009;119(3):e182]. Circulation. 2009;119(3):480-486.

44. Antman EM, Anbe DT, Armstrong PW, et al. ACC/AHA guidelines for the management of patients with ST-elevation myocardial infarction-executive summary. A report of the American College of Cardiology/American Heart Association Task Force on Practice Guidelines (Writing Committee to revise the 1999 guidelines for the management of patients with acute myocardial infarction). J Am Coll Cardiol. 2004;44(3):671-719.

45. The Platelet Receptor Inhibition for Ischemic Syndrome Management in Patients Limited by Unstable Signs and Symptoms (PRISM-PLUS) Trial Investigators. Inhibition of the platelet glycoprotein IIb/IIIa receptor with tirofiban in unstable angina and non-Q-wave myocardial infarction [published correction appears in NEngl J Med. 1998;339(6):415] N Engl J Med. 1998;338(21):1488-1497.

46. Yusuf S, Pearson M, Sterry H, et al. The entry ECG in the early diagnosis and prognostic stratification of patients with suspected acute myocardial infarction. Eur Heart J. 1984;5(9):690-696.

47. Brush JE Jr, Brand DA, Acampora D, Chalmer B, Wackers FJ. Use of the initial electrocardiogram to predict in-hospital complications of acute myocardial infarction. $N$ Engl J Med. 1985;312(18):1137-1141.

48. Anderson JL, Adams CD, Antman EM, et al. Writing Committee to revise the 2002 guidelines for the management of patients with unstable angina/non-ST-elevation myocardial infarction ACC/AHA 2007 guidelines for the management of patients with unstable angina/ non-ST-elevation myocardial infarction. J Am Coll Cardiol. 2007;50(7) e1-e157.
Therapeutics and Clinical Risk Management

\section{Publish your work in this journal}

Therapeutics and Clinical Risk Management is an international, peerreviewed journal of clinical therapeutics and risk management, focusing on concise rapid reporting of clinical studies in all therapeutic areas outcomes, safety, and programs for the effective, safe, and sustained use of medicines. This journal is indexed on PubMed Central, CAS,

\section{Dovepress}

EMBase, Scopus and the Elsevier Bibliographic databases. The manuscript management system is completely online and includes a very quick and fair peer-review system, which is all easy to use. Visit http://www.dovepress.com/testimonials.php to read real quotes from published authors. 